\title{
EFFECT OF SUPERPHOSPHATE ON THE MOBILIZATION OF NITROGEN IN A PEAT SOIL
}

\author{
Armi KaILA \\ University of Helsinki, Department of Agricultural Chemistry
}

Received April 18, 1958

Cultivated peat soils in Finland are generally rich in nitrogen. The author, e.g. found in 34 samples collected from different parts of our country total nitrogen contents which corresponded to amounts from 5.200 to $26.600 \mathrm{~kg} / \mathrm{ha}$ with an average of $14.400 \mathrm{~kg} / \mathrm{ha}$ in a $20 \mathrm{~cm}$ layer (1). In addition to the surface soil also the deeper layers must be taken into account. Thus the total nitrogen content of a peat soil may exceed nitrogen requirements of several hundreds of crops. Since this enormous supply of nitrogen almost completely occurs in organic forms its value to the plants depends on the velocity of its mineralization. Owing to the climatic conditions this mobilization of nitrogen often appears to be too slow as compared with the needs of the crops. This is particularly true in northern Finland.

In addition to the temperature all the other factors which exert their influence on the activity of soil microorganisms regulate the intensity of nitrogen mobilization. Among these are the nutrition conditions of the soil. When peat soils are in question special attention must be paid to the poor supply of phosphorus and potassium, common in our peat lands.

TuORILA (2) made an attempt to elucidate the effect of potassium and phosphorus fertilizers on the mobilization of peat nitrogen. He found that potassium tended to enhance the accumulation of ammonium nitrogen whereas phosphorus appeared to increase the nitrate nitrogen content of the experimental plots. The nitrogen uptake by crops was about $70--80 \mathrm{~kg} / \mathrm{ha}$ higher in plots treated with both potassium and phosphorus than in plots without treatments.

The material studied by Tuorila originated from field trials in Peat Experiment Station of Leteensuo in the southern part of Finland. The trials concerning annual treatments with increasing amounts of potash fertilizer and superphosphate, respectively, were then, it is in summer 1929, six years old. They are still running and in 1957 they were treated with these fertilizers for the 35th time. Thus these trials offer a valuable and in Finland unique opportunity to study the influence of 
long-time application of various amounts of fertilizers on the mobilization of nitrogen in peat soil.

Owing to the courtesy of the Board of Suoviljelysyhdistys (Peat Cultivation Society) and the staff of Leteensuo Experiment Station samples from one of these field trials, from "The experiment with increasing amounts of superphosphate on fen soil were placed at the author's disposal. In the present paper results from the study of these samples are reported.

\section{Material}

The field trial: The fen on which the field trial was placed was reclaimed in 1921 . The soil is fairly well humified wood-Carex-peat. In the spring 1923 the soil was clayed with $200 \mathrm{~m}^{3} / \mathrm{ha}$. The trial was started in the same year. Each treatment was in four replications and the plots were 45 square meters. The annual treatments of the plots analyzed in the present study were the following:

$$
\begin{aligned}
& \text { 1. } 0=\text { no superphosphate } \\
& \text { 2. } \mathrm{P}=100 \mathrm{~kg} / \text { ha of superphosphate } \\
& \text { 3. } 2 \mathrm{P}=200 " \text { " " } \\
& \text { 4. } 3 \mathrm{P}=300 \text { " }
\end{aligned}
$$

All the plots received equal amounts of $40 \%$ potash fertilizer annually. These varied from 100 to $300 \mathrm{~kg} / \mathrm{ha}$. No other nutrients were applied.

The experimental crops have been oats, wheat, green fodder and in most years timothy ley. In 1957 a yield of hay was harvested from a nine year old ley.

Soil samples were collected late in the autumn 1957. A special bore was employed and the different layers down to $70 \mathrm{~cm}$ were sampled. The corresponding samples of the replicate plots were intermixed. Combined samples from the two surface layers, or from the depths of 0 to $10 \mathrm{~cm}$ and 10 to $20 \mathrm{~cm}$, and from the layers 40 to $50 \mathrm{~cm}$ and 60 to $70 \mathrm{~cm}$ were used for the analyses and incubation experiment of the present study.

Hay samples were collected from all the four replicate plots of the four treatments. The samples were ground in a Wiley mill and analyzed separately.

\section{Methods}

Total nitrogen content of the soil and hay samples was determined by the common Kjeldahl procedure. Also the soil samples were air-dried and ground.

Since it had been found that even air-drying enhanced the ammonium nitrogen content of this kind of peat from two to five times, all the analyses of mineral nitrogen in peat samples were performed on fresh samples. Ammonium and nitrate nitrogen were extracted from 20 grams samples with $100 \mathrm{ml}$ of $5 \%$ potassium sulphate solution in which the samples were shaken for one hour. They were filtrated through paper and washed twice with $25 \mathrm{ml}$ of $5 \%$ potassium sulphate. One aliquote was used for the determination of nitrate nitrogen by the phenol-disulphonic acid method. From the rest of the extract ammonium nitrogen was distilled using magnesium oxide. 
The intensity of nitrogen mobilization in the peat samples was studied by incubating them for ten weeks in glass jars at laboratory temperature $\left(13^{\circ}-18^{\circ} \mathrm{C}\right)$. The original moisture content of the samples which corresponded to the conditions somewhat under the field capacity was maintained over the incubation period.

The $p H$-values were measured direct from the fresh peat with a Beckman $\mathrm{pH}-$ meter with glass electrode.

The phosphorus condition was characterized by the so-called mexchangeable phosphorus» or in this case the inorganic phosphorus extracted by $0.1 \mathrm{~N} \mathrm{KOH}-\mathrm{K}_{2} \mathrm{CO}_{3}$ solution when the ratio of soil to solution was 1 to 100 and the time of extraction was 18 hours.

The exchangeable potassium was extracted by $1 \mathrm{~N}$ ammonium chloride.

\section{Results}

Some characteristics of the peat samples. Since no statistically significant differences could be found between the variously treated peat of the corresponding layers in regard to their ash content, weight of volume, $\mathrm{pH}$, or content of total nitrogen, only the average values are reported. The following figures were obtained:

\begin{tabular}{rrrcc}
\multicolumn{1}{c}{ Layer } & ash \% & weight of volume & $\mathrm{pH}$ & total N \% \\
$0-10 \mathrm{~cm}$ & 35 & 0.47 & 4.3 & 2.2 \\
$10-20 \mathrm{~cm}$ & 37 & 0.52 & 4.4 & 2.3 \\
$40-50 \mathrm{~cm}$ & 15 & 0.33 & 5.0 & 2.5 \\
$60-70 \mathrm{~cm}$ & 13 & 0.28 & 5.1 & 2.5
\end{tabular}

The high ash content and weight of volume of the surface samples are, of course, due to the clay. It also makes the total nitrogen content per dry matter lower in the surface layers than in the deeper ones. If the nitrogen content is calculated as a percentage of ash-free dry matter, values from 3.4 to 3.6 per cent are obtained for the surface layers and 2.9 per cent for both of the deeper ones. It is of particular interest to notice the fairly low $\mathrm{pH}$-values of the surface samples.

The results of the determinations of mexchangeable phosphorus" and exchangeable potassium quite distinctly reflect the effect of different dressing with superphosphate:

\begin{tabular}{crrrrrrrr} 
& \multicolumn{3}{c}{ sexchangeable $\mathrm{P}$ ppm } & \multicolumn{3}{c}{ exchangeable K ppm } \\
layer & 0 & $\mathrm{P}$ & $2 \mathrm{P}$ & $3 \mathrm{P}$ & 0 & $\mathrm{P}$ & $2 \mathrm{P}$ & $3 \mathrm{P}$ \\
$0-10 \mathrm{~cm}$ & 34 & 70 & 93 & 306 & 650 & 375 & 310 & 225 \\
$10-20 \mathrm{~cm}$ & 23 & 46 & 62 & 104 & 520 & 155 & 130 & 115 \\
$40-50 \mathrm{~cm}$ & 18 & 28 & 28 & 29 & 215 & 90 & 70 & 80 \\
$60-70 \mathrm{~cm}$ & 5 & 17 & 7 & 14 & 105 & 60 & 60 & 45
\end{tabular}

In the surface layers the content of mexchangeable $P_{n}$ increases with the increasing application of superphosphate, but first the heaviest dressing has caused a marked accumulation of this kind of phosphorus. Some penetration of fertilizer phosphorus 
into deeper layers appears to have occurred, but particularly in the layer of 60 to $70 \mathrm{~cm}$ the content of mexchangeable $P_{n}$ is low in every treatment.

The potassium conditions, on the contrary, appear to be the better the lower the phosphate application has been. This, of course, arises from the fact that equal amounts of potash fertilizer have annually been applied to each plot and the considerably lower yields produced by the lower treatments with superphosphate have taken up less potassium than the higher ones in plots $2 \mathrm{P}$ and $3 \mathrm{P}$. The superiority of the 0 -plots to the treated plots can be found also in the potassium content of the deeper layers.

Thus the effect of the application of the total amounts of $0,3500,7000$, and $10500 \mathrm{~kg} / \mathrm{ha}$ of superphosphate, respectively, is revealed, at least, in the phosphorus and potassium conditions of the soils. Probably there are more or less distinct differences also in some other chemical characteristics, e.g. in the sulphate and calcium content, in the quality of the organic matter etc. In connection with the present study attention is paid only to the possible differences in the rate of mobilization of nitrogen.

Mineral nitrogen in peat samples. As soon as possible after the peat samples had been brought to the laboratory they were analyzed for ammonium and nitrate nitrogen. The results were obtained as $\mathrm{mg} / \mathrm{kg}$. Probably the values calculated on the volume basis would give a more representative picture of the conditions in nature. Owing to the fact that only volume weights determined on air-dried and ground samples were available, it was considered better to report the results in the more

Table 1. Mineral nitrogen in fresh peat samples. Expressed as $\mathrm{mg} / \mathrm{kg}$ of dry matter.

\begin{tabular}{|c|c|c|c|c|c|}
\hline \multirow[t]{2}{*}{ Layer } & \multicolumn{4}{|c|}{ Treatment } & \multirow[t]{2}{*}{ S.D. $5 \%$} \\
\hline & 0 & $\mathrm{P}$ & $2 \mathrm{P}$ & $3 \mathrm{P}$ & \\
\hline \multicolumn{6}{|c|}{$\mathrm{NH}_{4}-\mathrm{N}$} \\
\hline $0-10 \mathrm{~cm}$ & 28 & 59 & 45 & 49 & 18 \\
\hline $10-20 \mathrm{~cm}$ & 24 & 36 & 39 & 53 & 11 \\
\hline $40-50 \mathrm{~cm}$ & 36 & 53 & 83 & 81 & 27 \\
\hline $60-70 \mathrm{~cm}$ & 73 & 102 & 82 & 111 & 30 \\
\hline \multicolumn{6}{|c|}{$\mathrm{NO}_{3}-\mathrm{N}$} \\
\hline $0-10 \mathrm{~cm}$ & 42 & 55 & 81 & 111 & 15 \\
\hline $10-20 \mathrm{~cm}$ & 43 & 50 & 56 & 54 & 7 \\
\hline $40-50 \mathrm{~cm}$ & 45 & 40 & 43 & 70 & 8 \\
\hline $60-70 \mathrm{~cm}$ & 22 & 19 & 24 & 25 & 2 \\
\hline \multicolumn{6}{|c|}{$\mathrm{NH}_{4}-\mathrm{N}+\mathrm{NO}_{3}-\mathrm{N}$} \\
\hline $0-10 \mathrm{~cm}$ & 70 & 114 & 126 & 160 & 30 \\
\hline $10-20 \mathrm{~cm}$ & 67 & 86 & 95 & 107 & 12 \\
\hline $40-50 \mathrm{~cm}$ & 81 & 93 & 126 & 151 & 30 \\
\hline $60-70 \mathrm{~cm}$ & 95 & 121 & 106 & 136 & 31 \\
\hline
\end{tabular}


reliable original form. The main thing, the reliable comparison of the effect of various treatments on the mineral nitrogen content of the peat soil is possible, since the samples from each layers had equal weight of volume.

The data for ammonium nitrogen, nitrate nitrogen and their sum which represents the total mineral nitrogen in these samples are reported in Table 1 . The figures for significant differences at the 5 per cent level (S.D. $5 \%$ ) are calculated for each layer.

In the plots of the highest treatment with superphosphate both the ammonium and nitrate nitrogen contents as well as their sums are distinctly higher than in the untreated plots. The corresponding effect of the treatment $2 \mathrm{P}$ reaches down to the layer of 40 to $50 \mathrm{~cm}$, and that of the treatment $\mathrm{P}$ only to the two surface layers. The differences between the treated plots are less distinct, particularly between the plots $\mathrm{P}$ and $2 \mathrm{P}$, but the superiority of the plots $3 \mathrm{P}$ is in most cases indisputable.

It is of interest to compare these data with those recorded by Tuorila (2) during the summer 1929. He analyzed only the ploughing layer and reported his results as ammonium or nitrate nitrogen in $\mathrm{kg} / \mathrm{ha}$ in the $20 \mathrm{~cm}$ layer. In order to get comparable figures the present data are changed to the same units using the average of the values for the layers of 0 to $10 \mathrm{~cm}$ and 10 to $20 \mathrm{~cm}$.

\begin{tabular}{|c|c|c|c|c|}
\hline & \multicolumn{4}{|c|}{$\mathrm{NH}_{4}-\mathrm{N} \mathrm{kg} /$ ha in $20 \mathrm{~cm}$ layer } \\
\hline & 0 & $\mathrm{P}$ & $2 \mathrm{P}$ & $3 \mathrm{P}$ \\
\hline Tuorila, July 6th 1929 & 61 & 63 & 65 & 67 \\
\hline August 7th 1929 & 40 & 46 & 47 & 47 \\
\hline September 12th 1929 & 23 & 23 & 27 & 29 \\
\hline \multirow[t]{3}{*}{ Autumn 1957} & 16 & 47 & 41 & 51 \\
\hline & \multicolumn{4}{|c|}{$\mathrm{NO}_{3}-\mathrm{N} \mathrm{kg} / \mathrm{ha}$ in $20 \mathrm{~cm}$ layer } \\
\hline & 0 & $\mathbf{P}$ & $2 \mathrm{P}$ & $3 \mathrm{P}$ \\
\hline Tuorila, July 6th, 1929 & 18 & 22 & 23 & 25 \\
\hline August 7th 1929 & 11 & 11 & 10 & 10 \\
\hline September 12th 1929 & 4 & 4 & 8 & 5 \\
\hline Autumn 1957 & 42 & 51 & 67 & 80 \\
\hline
\end{tabular}

In 1929 the differences between the variously treated plots appear to have been almost insignificant. The data for ammonium nitrogen content are of the same magnitude in both years, but the nitrate nitrogen content seems to be considerably higher in the latter year. This, of course, may arise from the different analytical technique, but equally well it can be explained on the basis of the fact that late in the autumn the plants do not take up marked amounts of nitrogen, and nitrate nitrogen may accumulate. In both years the crop was timothy ley.

Incubation experiments. When soil samples are brought from field to laboratory the changes in the environmental conditions generally give rise to an intensive activity of microorganisms which probably had not occurred in field. In addition to this the effect of growing plants is ended. Attention must also be paid to the possible infection of the samples by microorganisms from the laboratory air. This may be of importance particularly when nitrification is studied, since it has been found in our 
Table 2. Mineral nitrogen in peat samples incubated for 5 weeks.

(Expressed as $\mathrm{mg} / \mathrm{kg}$ of dry matter.)

\begin{tabular}{|c|c|c|c|c|c|}
\hline \multirow[b]{2}{*}{ Layer } & \multicolumn{4}{|c|}{ Treatment } & \multirow[b]{2}{*}{ S.D. $5 \%$} \\
\hline & 0 & $\mathrm{P}$ & $2 \mathrm{P}$ & $3 \mathrm{P}$ & \\
\hline \multicolumn{6}{|c|}{$\mathrm{NH}_{4}-\mathrm{N}$} \\
\hline $0-10 \mathrm{~cm}$ & 50 & 55 & 46 & 54 & 27 \\
\hline $10-20 \mathrm{~cm}$ & 27 & 27 & 30 & 33 & 7 \\
\hline $40-50 \mathrm{~cm}$ & 88 & 92 & 73 & 81 & 53 \\
\hline $60-70 \mathrm{~cm}$ & 97 & 93 & 67 & 61 & 26 \\
\hline \multicolumn{6}{|c|}{$\mathrm{NO}_{3}-\mathrm{N}$} \\
\hline $0-10 \mathrm{~cm}$ & 257 & 296 & 355 & 449 & 61 \\
\hline $10-20 \mathrm{~cm}$ & 118 & 173 & 177 & 224 & 9 \\
\hline $40-50 \mathrm{~cm}$ & 121 & 137 & 114 & 178 & 10 \\
\hline $60-70 \mathrm{~cm}$ & 31 & 30 & 41 & 46 & 3 \\
\hline \multicolumn{6}{|c|}{$\mathrm{NH}_{4}-\mathrm{N}+\mathrm{NO}_{3}-\mathrm{N}$} \\
\hline $0-10 \mathrm{~cm}$ & 307 & 351 & 401 & 503 & 50 \\
\hline $10-20 \mathrm{~cm}$ & 145 & 200 & 207 & 257 & 10 \\
\hline $40-50 \mathrm{~cm}$ & 209 & 229 & 187 & 259 & 61 \\
\hline $60-70 \mathrm{~cm}$ & 128 & 123 & 108 & 107 & 28 \\
\hline
\end{tabular}

laboratory that in incubation experiments an intensive nitrification often takes place, at least after a certain period, although no activity of nitrification organisms could be detected in fresh samples of the same peat soil which were aseptically collected and handled. Thus incubation experiments under laboratory conditions do not relieve a reliable picture of the mobilization and changes of nitrogen in nature. Yet, they may be valuable when comparisons between various kinds of soils and between the effect of different treatments are in question.

In the incubation experiment of the present study samples were analyzed for ammonium and nitrate nitrogen after periods of five and ten weeks. The results are reported in Tables 2 and 3.

It could be expected that changes in the ammonium and nitrate nitrogen content of the samples had caused changes in the acidity of the peat. Yet, this soil appears to be very well buffered, and no significant increase or decrease in the $\mathrm{pH}$ values occurred due to the incubation.

According to the data in Tables 1 and 2 accumulation of nitrate nitrogen seems to have been intensive in the incubation period of the first five weeks. The ammonium nitrogen content is equal in the corresponding samples of the various treatments, except in the deepest layer where $2 \mathrm{P}$ and $3 \mathrm{P}$ samples contain less ammonium nitrogen than 0 and $P$ samples. Nitrate nitrogen content has increased in all the samples and the highest numbers were found for the samples of $3 \mathrm{P}$. Also in three layers the $2 \mathrm{P}$ samples contain significantly more nitrate nitrogen than do the 0 samples, but both in the surface layer and the deepest layer the $\mathrm{P}$ and 0 plots are equal in nitrate nitrogen content. 
Table 3. Mineral nitrogen in peat samples incubated for 10 weeks.

(Expressed as $\mathrm{mg} / \mathrm{kg}$ of dry matter.)

\begin{tabular}{|c|c|c|c|c|c|}
\hline \multirow[b]{2}{*}{ Layer } & \multicolumn{4}{|c|}{ Treatment } & \multirow[b]{2}{*}{ S.D. $5 \%$} \\
\hline & 0 & $\mathrm{P}$ & $2 \mathrm{P}$ & $3 \mathrm{P}$ & \\
\hline \multicolumn{6}{|c|}{$\mathrm{NH}_{4}-\mathrm{N}$} \\
\hline $0-10 \mathrm{~cm}$ & 67 & 87 & 71 & 87 & 24 \\
\hline $10-20 \mathrm{~cm}$ & 43 & 53 & 55 & 58 & 31 \\
\hline $40-50 \mathrm{~cm}$ & 128 & 92 & 110 & 66 & 22 \\
\hline $60-70 \mathrm{~cm}$ & 248 & 265 & 210 & 142 & 34 \\
\hline \multicolumn{6}{|c|}{$\mathrm{NO}_{3}-\mathrm{N}$} \\
\hline $0-10 \mathrm{~cm}$ & 499 & 554 & 563 & 743 & 69 \\
\hline $10-20 \mathrm{~cm}$ & 218 & 319 & 365 & 399 & 22 \\
\hline $40-50 \mathrm{~cm}$ & 223 & 245 & 212 & 288 & 10 \\
\hline $60-70 \mathrm{~cm}$ & 33 & 28 & 60 & 78 & 3 \\
\hline \multicolumn{6}{|c|}{$\mathrm{NH}_{4}-\mathrm{N}+\mathrm{NO}_{3}-\mathrm{N}$} \\
\hline $0-10 \mathrm{~cm}$ & 566 & 641 & 634 & 830 & 91 \\
\hline $10-20 \mathrm{~cm}$ & 261 & 372 & 420 & 457 & 43 \\
\hline $40-50 \mathrm{~cm}$ & 351 & 337 & 322 & 354 & 28 \\
\hline $60-70 \mathrm{~cm}$ & 281 & 293 & 270 & 220 & 38 \\
\hline
\end{tabular}

Thus the total content of plant available nitrogen is highest in the plots of the highest superphosphate dressing, except in the deepest layer where no difference exists between the variously treated plots. In plots to which lower amounts of superphosphate were applied only the surface layers are higher in total mineral nitrogen than the untreated ones.

The data in Table 3 indicate that during the prolonged incubation fairly intensive ammonification and nitrification have continued in all the samples. There are no differences in the ammonium nitrogen content except in the deeper layers where the untreated plot appears to contain the highest amounts. Differences in the nitrate nitrogen content are similar to those found in the samples incubated only for five weeks, and the same holds true also as to the total mineral nitrogen contents.

It is of interest to study the amounts of nitrogen mobilized during both the incubation periods of five weeks. The increase in the sums of the ammonium and nitrate nitrogen contents expressed as $\mathrm{mg} / \mathrm{kg}$ of dry matter were the following:

In 0 to 5 weeks:

$0-10 \mathrm{~cm}$

$10-20 \mathrm{~cm}$

$40-50 \mathrm{~cm}$

$60-70 \mathrm{~cm}$

In 5 to 10 weeks:

$0-10 \mathrm{~cm}$

$10-20 \mathrm{~cm}$

$40-50 \mathrm{~cm}$

$60-70 \mathrm{~cm}$

$\begin{array}{rcrr}0 & \mathrm{P} & 2 \mathrm{P} & 3 \mathrm{P} \\ 237 & 237 & 275 & 343 \\ 78 & 114 & 112 & 150 \\ 128 & 136 & 61 & 108 \\ 33 & 2 & 2 & -29\end{array}$

\section{9}


At the present there seems to be no simple method for the testing of the significance of the differences between such figures as the above ones which are obtained through subtraction to represent the amounts of mobilized nitrogen. Therefore, it may only be said that probably the mobilization of nitrogen of the surface layers has been most intensive in the plots treated with the highest amount of superphosphate, whereas the contrary seems to be true as to the deeper layers. The mobilization appears to have been of the same order of magnitude in both of the incubation periods except in the samples of the deepest layer. There has probably been some kind of "lag period» in these samples in the beginning of incubation.

Nitrogen in the yield. According to the results reported above the plant available nitrogen in this peat soil appears to be the higher the heavier the dressing with superphosphate. Now it is, of course, of interest to find out whether the corresponding differences can also be detected in the amounts of nitrogen taken up by the crop.

Owing to the courtesy of the staff of Leteensuo Experiment Station weights of the hay yields harvested in 1957 are available. The total nitrogen content of the hay samples was determined, and thus the nitrogen yield harvested in 1957 could be calculated. The results are in Table 4.

The yield without treatment has been very small, and although it contains a higher percentage of nitrogen than the yields of all the other treatments, its total nitrogen yield has remained extremely low. The percentage of nitrogen in the hay from the plots annually treated with 100 and $200 \mathrm{~kg} / \mathrm{ha}$ of superphosphate, respectively, is equal. Yet, the hay yield in the $2 \mathrm{P}$ plots has been significantly higher than that in the $\mathrm{P}$ plots and therefore also the amount of nitrogen taken up by the former yield is distinctly higher than that in the latter one. The yields from the $2 \mathrm{P}$ and $3 \mathrm{P}$ plots are equal, but there appears to be a tendency to a higher nitrogen content of the hay and also to a higher nitrogen yield in the $3 \mathrm{P}$ plots although the differences are not statistically significant.

It is probable that the failure of the plants to fully utilize the rich supply of phosphorus and nitrogen in the plots treated with the highest amount of superphosphate is partly due to the relatively poor supply of potassium in these plots. According to results which will be reported elsewhere the potassium percentage in the hay harvested from these plots is almost as low as the potassium content of hay from the plots of the same experiment which had been cultivated without any potash fertilizers. If the potassium conditions had been equal in all the plots, it is probable that the figures in Table 4 would have been different.

Table 4. Nitrogen in the hay yield in 1957

\begin{tabular}{cccc}
\hline Treatment & Yield kg/ha & N $\%$ & N yield kg/ha \\
\hline 0 & 310 & 2.31 & 7.0 \\
$\mathrm{P}$ & 5595 & 1.34 & 74.5 \\
$2 \mathrm{P}$ & 8070 & 1.39 & 112.2 \\
$3 \mathrm{P}$ & 8030 & 1.50 & 119.5 \\
\hline S. D. $5 \%$ & 440 & 0.26 & 12.8
\end{tabular}




\begin{tabular}{rccc}
\hline Treatment & Yield kg/ha & N \% & N yield kg/ha \\
\hline 0 & 1890 & 1.75 & 33.1 \\
$\mathrm{P}$ & 5040 & 1.60 & 80.7 \\
$2 \mathrm{P}$ & 5460 & 1.53 & 83.6 \\
$3 \mathrm{P}$ & 5930 & 1.48 & 87.8 \\
\hline S.D. $5 \%$ & 895 & 0.10 & 19.2
\end{tabular}

TUORILA (2) also reported results from the nitrogen uptake of crops in this experiment. To compare the differences in the conditions caused by the various treatments with superphosphate during a period of five years with those obtained thirty years later the data for nitrogen in the hay yield in 1927 are reported in Table 5 .

The differences in the yields of the various treatments are less marked than in 1957. Even the plots without treatment have produced a not insignificant hay crop. The yields of the $2 \mathrm{P}$ and $3 \mathrm{P}$ plots, on the other hand, are of the same order of magnitude as that of the $\mathrm{P}$ plots, and thus markedly lower than the corresponding crops in 1957. The nitrogen content of the hay appears to be slightly lower in the plots of the heaviest treatment and somewhat higher in the untreated plots than in the other ones. The nitrogen yields in the treated plots are equal and distinctly higher than in the untreated one. In 1957 the hay yield has taken up significantly more nitrogen than in 1927 from the plots treated with 200 and $300 \mathrm{~kg} / \mathrm{ha}$ of superphosphate, respectively. In the nitrogen yields of the plots treated with $100 \mathrm{~kg} / \mathrm{ha}$ of superphosphate there are no differences whereas the nitrogen uptake in the untreated plots has been markedly higher in 1927 .

\section{Discussion}

The different amounts of superphosphate applied to the experimental plots in 35 years have not only brought into the soil different quantities of phosphate but also different amounts of calcium and sulphate. On the other hand, the differences in the yields have caused more or less distinct differences in the uptake of all the nutrients. Thus, as the result of the treatments the nutritional conditions of the plots may have been even markedly changed. In the present study this was demonstrated in regard to potassium.

The plants in the variously treated plots do not only take up different amounts of nutrients. They also introduce into the soil new plant matter, and probably the quantities of roots and stubble remaining in the variously treated plots are different. This may effect the quality of the soil organic matter and also the microbiological processes occurring in soil. When mobilization of nitrogen is in question the fact must not be overlooked that plant residues are generally poor in nitrogen but rich in carbonaceous compounds available to microorganisms. On the other hand, it has been emphasized that introduction into soil of fresh organic matter intensifies the mineralization of soil organic matter. 
Thus the effects of prolonged treatments form a complicated problem. Whatever the factors involved are the results obtained in the present study indicate that when this peat soil has been annually treated with $0,100,200$, or $300 \mathrm{~kg} / \mathrm{ha}$ of superphosphate for 35 years the mineral nitrogen content of the soil and also the uptake of nitrogen by the crops are the higher the larger the superphosphate application. The differences between the treatments found in 1957 are far more distinct than those in 1927 and 1929 reported by TuORILA (2).

In spite of the high acidity of the surface layers of this peat soil nitrification organisms are able to be active in it. Obviously they were benefited from the superphosphate more than the ammonification organisms since the mineral nitrogen was accumulated mostly as nitrate particularly in the plots of the heavier treatments.

For the last nine years superphosphate was applied to the ley as surface dressing. Before the leys there had been several arable crops and the soil had been often ploughed during the experimental period. Therefore, it is natural that the effect of superphosphate is most distinct in the surface layers and particularly in the topmost one. However, it can be found that the highest application of superphosphate has exerted its effect on the mineral nitrogen content down to the layer of 60 to $70 \mathrm{~cm}$. Also the fairly modest treatment of $200 \mathrm{~kg} / \mathrm{ha}$ has in this respect reached down to the layer of 40 to $50 \mathrm{~cm}$.

\section{$S u m m a r y$}

The influence of superphosphate on the mobilization of nitrogen in a fen soil from Leteensuo Experiment Station in southern Finland was studied. Samples were used from a field trial in which superphosphate had been annually applied for 35 years in amounts of $0,100,200$, and $300 \mathrm{~kg} / \mathrm{ha}$, resp. Analyses were performed on samples of four layers: 0 to $10 \mathrm{~cm}, 10$ to $20 \mathrm{~cm}, 40$ to $50 \mathrm{~cm}$, and 60 to $70 \mathrm{~cm}$.

It was found that the mineral nitrogen $\left(\mathrm{NH}_{4}-\mathrm{N}+\mathrm{NO}_{3}-\mathrm{N}\right)$ content of the soil samples collected late in the autumn was in all layers highest in the plots treated with the highest amount of superphosphate. The positive effect of the treatment with $200 \mathrm{~kg} / \mathrm{ha}$ of superphosphate reached down to the layer of 40 to $50 \mathrm{~cm}$. In the soil treated with $100 \mathrm{~kg} / \mathrm{ha}$ the mineral nitrogen content was higher than in the untreated soil only in both surface layers.

In the incubation experiment of five and ten weeks the differences in the mineral nitrogen content were equalized, particularly in the samples from deeper layers. In the top layers the superiority of the heaviest treatment was maintained.

The amounts of nitrogen in the hay yields harvested in the previous summer appeared, generally, to be the higher the larger the amounts of superphosphate applied. It seemed to be probable that potassium was a minimum factor in the plots of the heaviest superphosphate treatment.

Comparison of the present results with data obtained from the same experiment when it had been only run for five years indicated that, in regard to the availability of nitrogen in this peat soil, the slight tendency found thirty years ago had grown to the distinct superiority of the heavy superphosphate treatment. 


\title{
REFERENCES
}

(1) KAIlA, A. 1948. Viljelysmaan orgaanisesta fosforista (Summary: On the organic phosphorus in cultivated soils). Valt. maatal.koet. julk. 129. Helsinki, 118 p.

(2) Tuoril. A, P. 1933. Beitrag zur Kenntnis des Einflusses der Kali- und Phosphorsäuredüngung auf die Mobilisation des Moorbodenstickstoffes. Wissensch. Veröffentl. Finn. Moorkulturver. N:o 17, Helsinki, 52 p.

\section{S E L OST U S :}

\section{SUPERFOSFAATIN VAIKUTUKSESTA TURPEEN TYPEN MOBILISOITUMISEEN}

\author{
Armi Kaila
}

\section{Yliopiston maanviljelyskemian laitos, Helsinki}

Tutkimuksen kohteena oli Leteensuon koeaseman Koe enenevillä fosforihappomäärillä mutasuollas. Kokeessa on täysin lannoittamattoman jäsenen lisäksi, jota ei tässä tutkimuksessa analysoitu, neljä koejäsentä, jotka ovat vuosittain saaneet saman määrän kalisuolaa sekä $0,100,200$ tai $300 \mathrm{~kg} / \mathrm{ha}$ superfosfaattia. Näytteet otettiin kesän 1957 heinäsadosta, joka korjattiin yhdeksännestä nurmesta, sekä saman vuoden syksyllä maan eri kerroksista. Kerrokset $0-10 \mathrm{~cm}, 10-20 \mathrm{~cm}, 40-50 \mathrm{~cm}$ ja $60-70$ $\mathrm{cm}$ otettiin analysoitaviksi.

Todettiin, että kaikissa kerroksissa tuoreiden näytteiden mineraalitypen $\left(\mathrm{NH}_{4} \mathbf{-}^{-} \mathrm{NO}_{2}-\mathrm{N}\right)$ pitoisuus oli suurin eniten superfosfaattia saaneessa koejäsenessä. Vuosittain $200 \mathrm{~kg} / \mathrm{ha}$ saanut koejäsen sisälsi kolmessa ylimmässä kerroksessa, $100 \mathrm{~kg} / \mathrm{ha}$ saanut vain kahdessa ylimmässä kerroksessa enemmän mineraalityppeä kuin lannoittamaton.

Muhitettaessa näytteitä laboratoriossa 5 ja 10 viikkoa tasoittuivat erot näytteiden mineraalitypen pitoisuuden välillä melkoisesti, mutta suurimman superfosfaattilannoituksen saanut koejäsen pysyi jatkuvasti muita parempana.

Heinäsatojen ottamat typen määrät olivat yleensä sitä suuremmat mitä runsaampi superfosfaattilannoitus oli annettu. Todennäköisesti kalin niukkuus esti osaltaan kasveja käyttämästä täysin hyväkseen runsaimmin lannoitetun koejäsenen käyttökelpoisia typpi- ja fosforivaroja.

TUORILAN vuosina $1927-29$ tästä kokeesta saamat tulokset olivat samansuuntaisia, mutta erot olivat paljon pienempiä kuin nyt noin kolmekymmentä vuotta myöhemmin. 